\title{
Evaluation of fluctuating asymmetry and sexual dimorphism of Channa striata using landmark-based geometric morphometric analysis from Agusan Marsh and Lake Mainit in Caraga Region, Philippines
}

\author{
REX BOMVET D. SAURA, ${ }^{1, \vartheta}$ GENEVEVE C. FALCASANTOS, ${ }^{2}$ REX JR. M. ANDANTE ${ }^{3}$, LUNA C. MUNDA $^{4}$, \\ MARYCRIS M. ALIMORONG ${ }^{5}$, BRENT JOY HERNANDO ${ }^{6}$ \\ ${ }^{1}$ Surigao State College of Technology-Mainit Campus, Surigao del Norte, Philippines. "email: saura.rex @ yahoo.com. \\ ${ }^{2}$ Asian College Foundation, Butuan City, Agusan del Norte, Philippines \\ ${ }^{3}$ Senior High School, Agusan del Sur National High School, San Francisco, Agusan del Sur, Philippines \\ ${ }^{4}$ Special Science, Anticala National High School, Anticala Butuan City, Agusan del Norte, Philippines \\ ${ }^{5}$ Senior High School Teacher, Jabonga National High School, Jabonga, Agusan del Norte, Philippines \\ ${ }^{6}$ Department of Biology, College of Arts and Science, Caraga State University, Ampayon, Butuan City, Agusan del Norte, Philippines.
}

Manuscript received: 26 October 2020. Revision accepted: 25 April 2021.

\begin{abstract}
Saura EBD, Falcasantos GC, Andante RJM, Munda LC, Alimorong MM, Hernando BJ. 2021. Evaluation of fluctuating asymmetry and sexual dimorphism of Channa striata using landmark-based geometric morphometric analysis from Agusan Marsh and Lake Mainit in Caraga Region, Philippines. Nusantara Bioscience 13: 100-110. Evaluation was conducted to determine the impact of ecological condition to Channa striata using fluctuating asymmetry (FA) employing the landmark-based geometric morphometric analysis, using TPS software, SAGE, PAST-Hotellings Test, including Physico-chemical analysis, cyanide and four base metals. Results of Physico-chemical analysis of the two habitats showed Agusan marsh with low oxygen level (3.37-4.55) and high in Iron and TDS as compared to DENR Standards. The statistical results showed high variations $(p<0.0001)$ on left and right-side having percentage of 79.22\% in Agusan Marsh and 72.35\% in Lake Mainit which is relatively high Fluctuating Asymmetry. In terms of sex, Agusan marsh had $84.27 \%$ and $85.41 \%$ FA in males and females while Lake Mainit having $85.12 \%$ and $80.89 \%$ in males and females. The fairly similar percentage of Fluctuating Asymmetry confirms no sexual dimorphism and no shape differences between male and female, and no peculiar characters to distinguished between sexes based on the 17 landmark points. Present study concluded that FA observed in the snout tip was due to breeding behavior, the landmark points in cephalic, pectoral, and caudal region were associated with burrowing and mobility factors within the lateral line system in these fishes which thrive in high turbid habitat and low oxygen. Furthermore, it was found that the level of FA tends to increase in disturbed environs.
\end{abstract}

Keywords: Phenotypic Plasticity, Physico-chemical parameters, Procrustes shape coordinates, Variation

\section{INTRODUCTION}

Character variation among populations describing the external morphology and accompanied differences between sexes are basic concepts in systematics. The magnitude of phenotypic differences such as body shapes, sexual dimorphism, and allometry is perhaps a reflection of the partitioning between sexes, availability of food, seasonal or climatic patterns, inter-relationship among organisms in their respective habitat which is often correlated to geographical factors (Broadley 1965; Sullivan and Best 1997).

The variability of attributes such as body shape, color, sizes and related to sex phenotypic characteristics among species are annotated as "sexual dimorphisms" (McCombe and Greer 2014). Such characteristics lead to an instinct of rivalry amongst individuals in the interior of each sex and mate selection based on morphological and behavioral traits (Ralls and Mesnick 2009; Vitt and Caldwell 2014). Geographical variation denotes dissimilarities between species in inherently founded characters through the habitat's natural topography. Studies on geographic variation of a number of organisms highlight clarity on causes and significance of microevolution (Olvido 2012; Wu et al. 2015). At the global level, geographic variation in phenotypic plasticity is in part due to genetic differences acquired via long-term natural selection to produce adaptation to different environments (Niskanen et al. 2017). The degree of phenotypic plasticity in life-history traits differs among species and these differences are adaptive and non-adaptive in various habitats (Lymbery 1992; Seigel and Ford 2001). Habitat conditions have a tendency to reduce equilibrium stability in the developmental aspect of aquatic organisms e.g. small and random deviations from bilaterally symmetrical traits leading to Fluctuating Asymmetry (FA) (Santos et al. 2013). Stressed marginal habitats tend to influence increasing asymmetry as well as genetic perturbations (Parsons 1992). FA has been used as an ecological indicator in studies of natural and sexual selection and as a reliable bio-indicator tool relevant in environmental monitoring and conservation biology (Leary and Allendorf 1989; Tomkins and Kotiaho 2001; Beasley et al. 2013; Coda et al. 2017). 
Furthermore, landmark-based Geometric morphometrics offers a powerful approach in computing morphological variables and covariation of shape (Rohlf 2000; Adams et al. 2009; Webster and Sheets 2010). Such techniques utilize statistical analysis on morphological variables based on Cartesian landmark coordinates. The traditional morphometrics separates shape from overall size, position, and orientation of the landmark configurations and the resulting Procrustes shape coordinates are used for statistical analysis (Mitteroecker and Gunz 2009).

The present study was conducted on the fish species Channa striata of Channidae (Bloch 1973) commonly known as Chevron Snakehead which is a non-native and invasive species to Philippines. Though in wild a burrowing dweller of bottom of mud lakes, canals, and swamps and living and breeding in turbid and low levels (Phen et al. 2005; Cagauan 2007), in other cases cultured for commercial food production (Guerrero III 2014). These fish are capable of limited movement overland by the use of a wriggling motion which they use to disperse to new water bodies on rainy nights (Sayer 2005). C. striata have eyes, but given the turbid habitats they live in, they may also use other sensory mechanisms to find prey and mates. They have a lateral line system that detects small changes in water pressure that help them to be aware of the objects moving in the water around them (Kasumyan 2003; Musikasinthorn 2004). The capacity of the folds of skin to distend is an important adaptation enabling the jaws to protrude and assist the fish to engulf relatively large-size prey (Mittal and Agrawal 1994).

Present study aims to compare the levels of FA, sexual dimorphism, and body variations of $C$. striata collected from two separate inland waters Agusan Marsh and Lake Mainit of Caraga Region Philippines using landmark-based geometric morphometric analysis. These include the assessment of Physico-chemical parameters, Cyanide and four base metals; Copper, Lead, Zinc, Iron of the study area. The study would provide knowledge on the character variation of $C$. striata and give relevant information useful in policy making and formulation of ecosystem-based management plan to the immediate agency for environmental protection in Agusan Marsh and Lake Mainit.

\section{MATERIALS AND METHODS}

\section{Study Area}

The study was conducted in two different types of inland waters namely Agusan Marsh, Agusan del Sur, and Lake Mainit, Surigao del Norte of Caraga Region, Philippines. The ecological aspects were recorded and coordinates of the six sampling stations on each area were obtained using geocam mobile app, as presented in Table 1 and a map was generated (Figure 1).

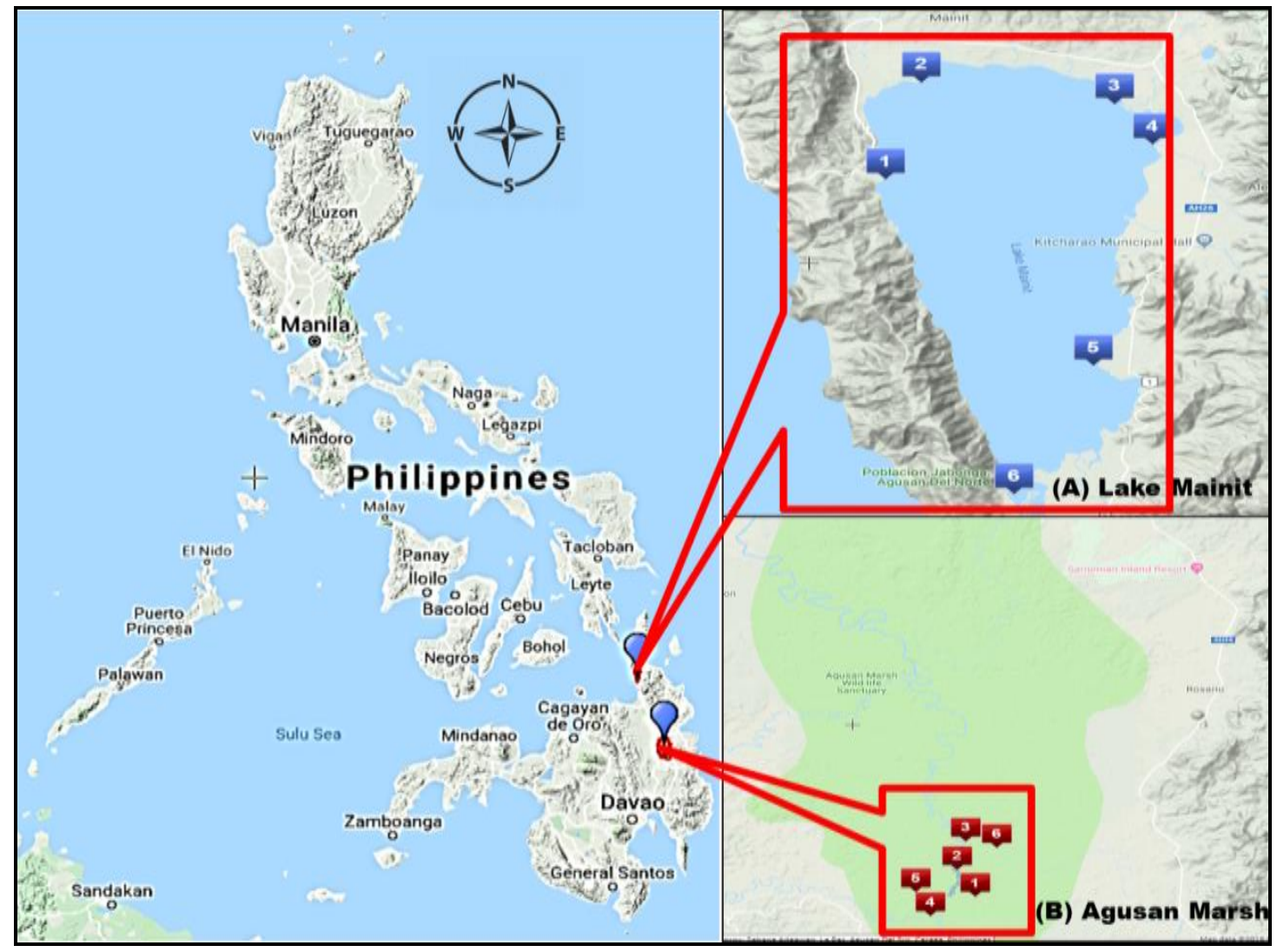

Figure 1. Map of geographically separate habitat of Channa striata (Chevron Snakehead) samples in Caraga Region, Philippines: A. Lake Mainit (17,060 hectares showing the six (6) water sampling stations, B. Agusan Marsh (14,835 hectares) showing the six (6) sampling stations water on the southern portion. 
Table 1. Site Characteristics of the sampling stations established in Lake Mainit and Agusan Marsh, Philippines

\begin{tabular}{|c|c|c|}
\hline Sampling areas & Coordinates & Site characteristics \\
\hline \multicolumn{3}{|l|}{ Lake Mainit } \\
\hline Station 1 & $\begin{array}{l}9^{\circ} 28^{\prime} 59^{\prime \prime} \mathrm{N} \\
125^{\circ} 28^{\prime} 49^{\prime \prime} \mathrm{E}\end{array}$ & $\begin{array}{l}\text { River mouth of Tagbuyawan, few residents, rocky riverbanks and substrate, diverse plants in } \\
\text { the sloping areas of the Malimono Mountain range Active fishing and navigation within the } \\
\text { Lake. Previous site of Cyanide gold processing area in nearby areas. }\end{array}$ \\
\hline Station 2 & $\begin{array}{l}9^{\circ} 31^{\prime} 35^{\prime \prime} \mathrm{N} \\
125^{\circ} 29^{\prime} 27^{\prime \prime} \mathrm{E}\end{array}$ & $\begin{array}{l}\text { River mouth of Mayag sedges and grass dominant in the riparian area and shrub plants to trees } \\
\text { are present in the upland areas, active fishing and navigation were observed, residential areas } \\
\text { and agricultural land }\end{array}$ \\
\hline Station 3 & $\begin{array}{l}9^{\circ} 31^{\prime} 1^{\prime \prime} \mathrm{N} \\
125^{\circ} 33^{\prime} 2^{\prime \prime} \mathrm{E}\end{array}$ & $\begin{array}{l}\text { River mouth of Magpayang, sedges and grass dominant in the riparian area and shrub plants to } \\
\text { trees, coconut plants in the upper stream areas and obvious landscape of large scale mining, } \\
\text { few live stocks, and agricultural lands like rice fields, several residential areas, and } \\
\text { establishments. Active fishing and navigation. }\end{array}$ \\
\hline Station 4 & $\begin{array}{l}9^{\circ} 29^{\prime} 54^{\prime \prime} \mathrm{N} \\
125^{\circ} 33^{\prime} 45^{\prime \prime} \mathrm{E}\end{array}$ & $\begin{array}{l}\text { River mouth of Magtiaco with sandy river banks, sedges and grass dominant in the riparian } \\
\text { area and shrub plants to trees, coconut plants are present in the upper stream areas and obvious } \\
\text { landscape of small-scale gold mining, few live stocks, agricultural land like rice fields, several } \\
\text { residential areas. Active fishing and navigation. }\end{array}$ \\
\hline Station 5 & $\begin{array}{l}9^{\circ} 23 ’ 51 ’ \mathrm{~N} \\
125^{\circ} 32^{\prime} 40^{\prime} \mathrm{E}\end{array}$ & $\begin{array}{l}\text { River mouth of Jaliobong, cattails plants dominant in the littoral zone with floating water lilies } \\
\text { and water hyacinth, Agricultural land and residential areas in the nearby upstream. Active } \\
\text { fishing and navigation within the Lake. }\end{array}$ \\
\hline Station 6 & $\begin{array}{l}\text { 9'20’20”N } \\
125^{\circ} 31 ' 11 ” \mathrm{E}\end{array}$ & $\begin{array}{l}\text { Kalinawan river as outlet of the lake, cattails dominated the littoral zone, near to the resort, } \\
\text { nearby areas are present with residents, on-going operation for flood control project in the } \\
\text { upper stream. }\end{array}$ \\
\hline \multicolumn{3}{|l|}{ Agusan Marsh } \\
\hline Station 1 & $\begin{array}{l}8^{\circ} 11^{\prime} 16^{\prime \prime} \mathrm{N} \\
125^{\circ} 54^{\prime} 50^{\prime \prime} \mathrm{E}\end{array}$ & $\begin{array}{l}\text { The lake basin of Mihaba dominated by water hyacinth and few disperse trees agricultural land } \\
\text { and mining in the nearby environs }\end{array}$ \\
\hline Station 2 & $\begin{array}{l}8^{\circ} 12^{\prime} 15^{\prime \prime} \mathrm{N} \\
125^{\circ} 54^{\prime} 16^{\prime \prime} \mathrm{E}\end{array}$ & $\begin{array}{l}\text { Creek outlet of Lake Mihaba riparian vegetation is cattails and sedges with few trees and } \\
\text { agricultural land and mining in the upper streams. Active navigation was observed. }\end{array}$ \\
\hline Station 3 & $\begin{array}{l}9^{\circ} 13^{\prime} 16^{\prime \prime} \mathrm{N} \\
125^{\circ} 54^{\prime} 29^{\prime \prime} \mathrm{E}\end{array}$ & $\begin{array}{l}\text { Near to the intersection of by cattails and sedges with few trees and agricultural land and } \\
\text { mining in the upper streams. Active navigation was observed }\end{array}$ \\
\hline Station 4 & $\begin{array}{l}8^{\circ} 10^{\prime} 411^{\prime \prime} \mathrm{N} \\
125^{\circ} 533^{\prime} 40^{\prime \prime} \mathrm{E}\end{array}$ & $\begin{array}{l}\text { The Loreto river end of mixing to Agusan river, river waters flowing from the northeastern of } \\
\text { Bukidnon }\end{array}$ \\
\hline Station 5 & $\begin{array}{l}8^{\circ} 10^{\prime} 48^{\prime \prime} \mathrm{N} \\
125^{\circ} 533^{\prime} 44^{\prime \prime} \mathrm{E}\end{array}$ & $\begin{array}{l}\text { The neck of three headwaters from Bukidnon, Simulao river and Lake Mihaba drainage creek, } \\
\text { riparian dominated by tall grass and sedges. Active navigation was observed }\end{array}$ \\
\hline Station 6 & $\begin{array}{l}9^{\circ} 13^{\prime} 22^{\prime \prime} \mathrm{N} \\
125^{\circ} 54^{\prime} 14^{\prime \prime} \mathrm{E}\end{array}$ & $\begin{array}{l}\text { Downstream of Simulao River, riparian dominated by cattails and sedges with few trees and } \\
\text { agricultural land and mining in the upper streams. Active navigation was observed }\end{array}$ \\
\hline
\end{tabular}

\section{Establishment and collection of water and Physico- chemical analysis}

The water samples were collected from two different types of inland waters in CARAGA region in Lake Mainit and Agusan Marsh respectively. Six sampling stations were established in each area. The water samples were collected through depth of $1-50 \mathrm{~cm}$ of the water column of each sampling site. The physicochemical parameters of each sampling station in every area were done using HANNA HI98194 multi-parameter test. Water samples were collected @ 0.5 L per sample and placed directly in calibrated PET bottles. The bottles were sealed tightly and labeled with information of area, station, and date of collection and photographed for documentation. A total of six bottles with $0.5 \mathrm{~L}$ water samples from Lake Mainit were collected on 26.11.2018 and another six bottles from Agusan Marsh were collected on 05.12.2018. The samples were chilled in ice bucket and delivered to Philsaga Mining Assay Laboratory, Rosario, Bunawan, Agusan del Sur for the analysis of Cyanide and Four Base Metals.

\section{Collection of fish samples and preparation for landmarking}

The fresh and live samples of $C$. striata were obtained from the local fishermen folks of Agusan Marsh and Lake Mainit. A total of sixty fish samples, out of which thirty males and thirty females were collected during 1315.11.2018 from Lake Mainit. Another sixty fish samples, with equal sex proportion, were obtained on 22.11.2018 from Agusan Marsh. The length of each fish sample was determined by measuring the specimen from its snout down to the caudal fin using measuring tape and weighed using BATVOX ACS-40 digital weighing scale with $40 \mathrm{~kg}$ capacity and 1/3000 F.S. precision. The individual fish was flanked on a Styrofoam and fins were pinned showing its point of origin. Photographs of the left and right side of each specimen were taken with canon eos 1200D for landmarking. Specimens were dissected individually for their sex determination. 
Table 2. Description of the landmark points in the body shape of Channa striata adopted and modified from Saura and Andante (2018).

\begin{tabular}{ll}
\hline Coordinates & Location \\
\hline 1 & Snout Tip \\
2 & End of head length \\
3 & anterior junction of the dorsal fins \\
4 & Posterior junction of the dorsal fins \\
5 & Dorsal insertion of caudal fin \\
6 & Midpoint of caudal border of hypural plate \\
7 & Ventral insertion of caudal fin \\
8 & Posterior insertion of anal fin \\
9 & Anterior insertion of anal fin \\
10 & Posterior insertion in the dorsal base of pelvic fin \\
11. & Anterior insertion in the dorsal base of pelvic fin \\
12 & Ventral end of lower jaw articulation \\
13 & Posterior end of maxilla \\
14 & Anterior margin through midline of orbit \\
15 & Posterior margin through midline of orbit \\
16 & Dorsal end of operculum \\
17 & Dorsal base of pectoral fin \\
\hline
\end{tabular}

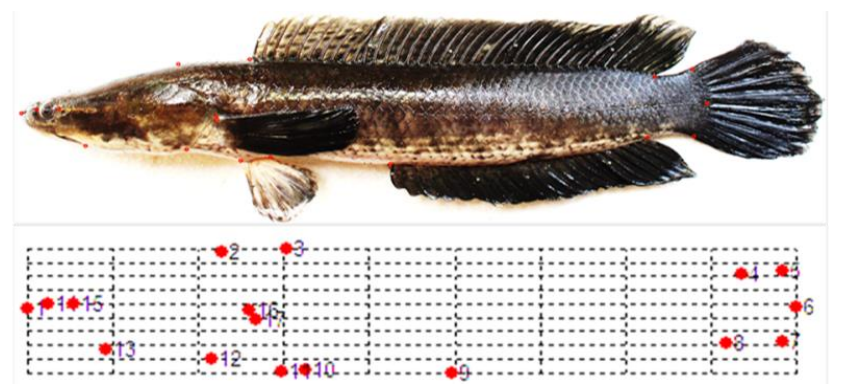

Figure 2. Actualized image of digitized selected landmark point of Channa striata.

\section{Selection of Land-marking selection and digitizing}

The images of fish specimens were sorted by sexes and the images processed in tpsUtil64 to create *.tps files. The resultant tps files were digitized with 17 landmarks using tpsDig2 software. The location of the landmarks and anatomical descriptions were represented in Table 2 and Figure 2. Landmarking was referred to on stickleback fish model of anyfish.com.

\section{Shape analysis}

The Procrustes superimposition was performed on the digitized image samples through tps relwarp software by subsequently pressing the clickable buttons of the consensus, partial warps, and the relative warp scores report and was saved for the statistical analysis for sexual dimorphism. Further, the digitized images were subjected to Symmetry and Asymmetry Geometric Data (SAGE) v.1.21 software following the protocols for object symmetry which is the landmark pairing protocol and matching symmetry, a side identification protocol to determine the shape conformation of individual variations (symmetric, asymmetric and error) and counting the possible covariance. In addition, the SAGE software platform provided options for the Principal Component Analysis (PCA) which was utilized to determine the affected landmark, and only the first four PCA\% and deformation grid results of C. striata from Agusan Marsh and Lake Mainit and respective sexes were obtained.

\section{Statistical analysis}

The cumulative report saved from relative warp analysis was subjected to PAST 3 software for discriminant analysis and to derived plot for sexual dimorphisms and Hotellings $\mathrm{T}^{2}$ test was used to determine significant differences of the sex shape differences. Further, the Procrustes method was employed and the significant differences of fluctuating asymmetry values respective to habitat and sexes were assessed using SAGE v.1.21 software. Permutation default statistical analysis i.e. Procrustes ANOVA procedure for understanding interaction and side effects were carried out in SAGE software.

\section{Data analysis}

The physicochemical parameters, content of cyanide, and four base metals, Lead, Copper, Zinc, Iron in water samples were compared to DENR standards (national water quality standards) above or below the maximum contamination level. Furthermore, the data of relative warp analysis, discriminant analysis, sexual dimorphism, and FA obtained from both the sexes of $C$. striata both Lake Mainit and Agusan Marsh were describe and compared.

\section{RESULTS AND DISCUSSIONS}

\section{Fluctuating asymmetry}

A total of one hundred twenty $C$. striata fish samples were obtained for this study, sixty from Lake Mainit and another sixty (60) from Agusan marsh. The length and weight of the fish samples from pond and Lake Mainit was presented in Table 3.

Table 3. Total Length and total weight of Channa striata from Lake Mainit and Agusan Marsh collected in the month of November 2018.

\begin{tabular}{lccccccc}
\hline \multirow{2}{*}{ Fish samples } & \multirow{2}{*}{ N } & Range & Total length $(\mathbf{c m})$ & \multicolumn{3}{c}{ Total weight (g) } \\
& & Mean & SD \pm SE & Range & Mean & SD \pm SE \\
\hline Lake Mainit & 60 & $30.0-41.9$ & 34.96 & $2.3 \pm 0.3$ & $205-480$ & 318.83 & $64.3 \pm 8.3$ \\
Agusan Marsh & 60 & $29.5-41.1$ & 36.2 & $2.8 \pm 0.3$ & $180-565$ & 391.1 & $89.7 \pm 11.6$ \\
\hline
\end{tabular}

Note: N-total number of samples 
Furthermore, Procrustes method was used to assess the FA value of the right and left side of $C$. striata pooled samples both from Agusan Marsh and Lake Mainit are presented in Table 4 . The individual symmetry and sides of Left and Right body shape in Agusan Marsh and Lake Mainit were not statistically significant. Out of the three effects considered, two effects (Individual and Sides) showed high significance $(\mathrm{p}<0.0001)$ in both Agusan Marsh and Lake Mainit pooled samples. It indicated the incidence of FA in $C$. striata which was attributed to the effects of environmental stressors which can cause developmental instability to the species. Similar reports of developmental instability caused by the effects of stressed environment were observed in goby fish Glossogobius giuris from Agusan river samples (Jumawan et al 2016) and in the wings of Aedes albopictus from selected barangays in Iligan City, Philippines (Quirog and Tabugo 2015).

The principal component analysis (PCA) was employed on both pooled samples Agusan Marsh and Lake Mainit to determined landmark points affected (Table 5). Samples of C. striata from Agusan Marsh showed a total of $79.22 \%$ of FA from PC1-PC4. PC1 showed that all areas covered by these landmarks were found to have greater asymmetry. On the other hand, Lake Mainit $C$. striata showed a total FA interaction of $72.35 \%$ from PC1 to PC4. Affected landmarks were greater in PCA 3. This indicated the bilateral asymmetry of both male and female species of each habitat. The Agusan marsh $C$. striata population experienced a higher level of environmental stress. The asymmetrical shape of $C$. striata from Agusan Marsh and Lake Mainit fishes were compared and shown in Figure 3.

The individual symmetry and sides of left and right body shape of male and female in Agusan Marsh and Lake Mainit were not statistically significant shown in Table 6 and Table 7. Both male and female from two populations, out of the three effects considered, two shows high significance $(\mathrm{p}<0.0001)$ both individuals and sides which is depicted.

Table 4. Procrustes ANOVA results of pooled fish sample of Channa striata from two habitats.

\begin{tabular}{|c|c|c|c|c|c|}
\hline Effect & Sum of Squares & $\begin{array}{c}\text { Degrees of } \\
\text { freedom }\end{array}$ & $\begin{array}{c}\text { Mean } \\
\text { square }\end{array}$ & F-value & p-value \\
\hline \multicolumn{6}{|l|}{ Agusan Marsh } \\
\hline Individuals & 0.1216 & 1770 & 0.0001 & 3.2236 & $0 *$ \\
\hline Individual x Sides & 0.0377 & 1770 & 0 & 0.06928 & $1^{\mathrm{ns}}$ \\
\hline Measurement Error & 0.11075 & 3600 & 3.0764 & --- & --- \\
\hline \multicolumn{6}{|l|}{ Lake Mainit } \\
\hline Sides & 0.0044 & 30 & 0.0001 & 7.8103 & $0^{*}$ \\
\hline Individual x Sides & 0.0331 & 1770 & 0 & 0.4114 & $1^{\mathrm{ns}}$ \\
\hline Measurement Error & 0.16366 & 3600 & 4.5462 & --- & --- \\
\hline
\end{tabular}

Note: *highly significant ( $\mathrm{p}<0.0001)$, ns not significant.

Table 5. The results of first four (4) Principal Components of Channa striata from Agusan Marsh and Lake Mainit.

\begin{tabular}{ccccc}
\hline PCA & $\begin{array}{c}\text { Individual } \\
\text { (symmetry) }\end{array}$ & $\begin{array}{c}\text { Sides } \\
\text { (directional } \\
\text { asymmetry) }\end{array}$ & $\begin{array}{c}\text { Interaction } \\
\text { (fluctuating } \\
\text { asymmetry) }\end{array}$ & Landmarks affected \\
\hline Agusan Marsh & & & & \\
PC1 (\%) & 44.31 & $100 \%$ & 43.15 & $1,2,5,6,7,9,11,12,13,14,15,16,17$ \\
PC2 (\%) & 17.61 & & 18.93 & $1,2,3,5,7,9,10,11,12,14,15,16$ \\
PC3 (\%) & 13.93 & & 9.69 & $1,6,7,10,11,14,15,16,17$ \\
PC4 (\%) & 5.83 & & 7.43 & $2,5,7,8,9$ \\
Overal\% & 81.68 & & 79.22 & \\
Lake Mainit & & & \\
PC1 (\%) & 61.01 & $100 \%$ & 29.88 & $1,2,3,6,10,13,14,15,16,17$ \\
PC2 (\%) & 15.69 & & 20.91 & $1,2,7,9,10,11,12,14,16,17$ \\
PC3 (\%) & 6.56 & & 12.33 & $1,2,3,5,6,8,9,10,11,12,13,14,15,17$ \\
PC4 (\%) & 5.17 & & 9.23 & $1,2,3,5,9,11,12,16,17$ \\
Overall\% & 88.52 & & 72.35 & \\
\hline
\end{tabular}



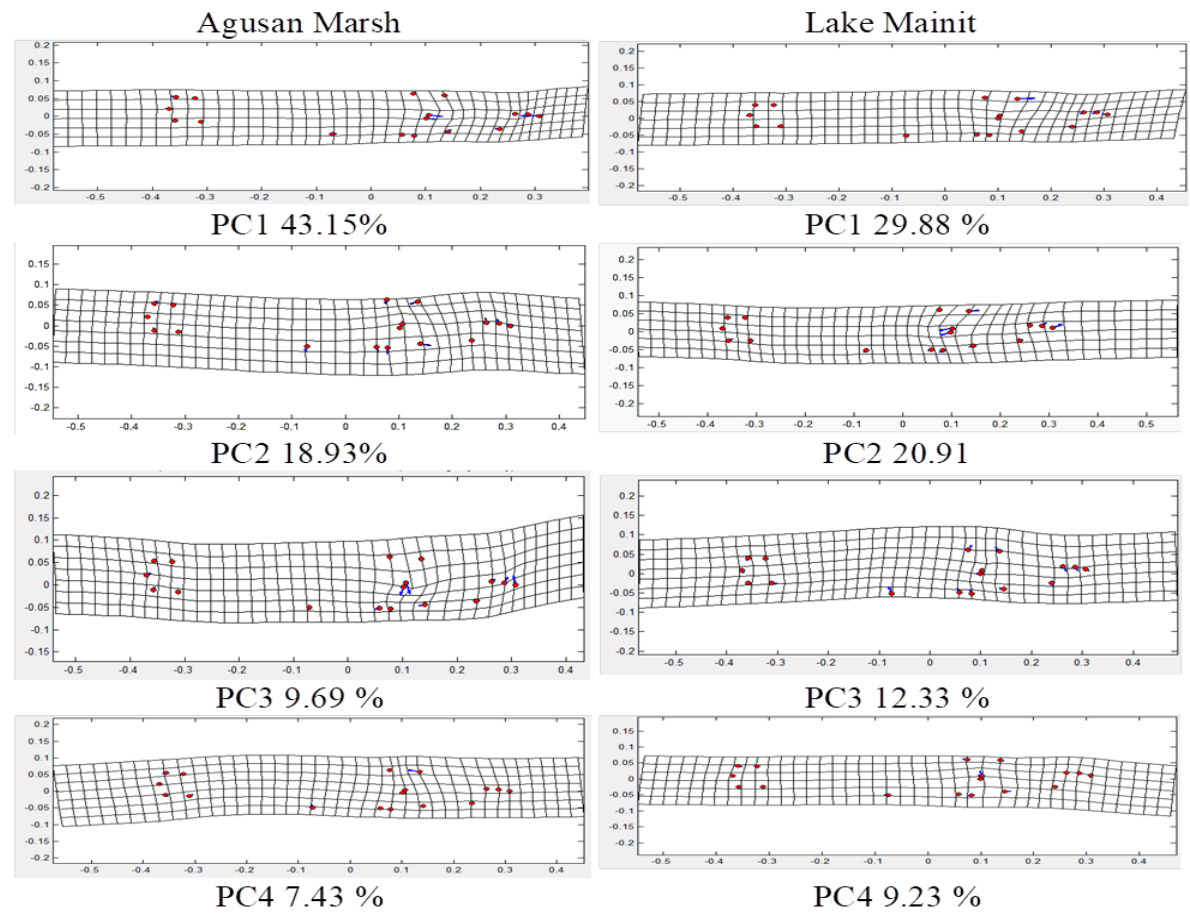

Figure 3. PCA implied deformation for individual $\times$ side interaction of fluctuating asymmetry of Channa striata from Agusan Marsh (first column) and Lake Mainit (second column) (zoom in to see blue arrows implies degree)

Table 6. Procrustes ANOVA results of Channa striata from Agusan Marsh in terms of sexes.

\begin{tabular}{|c|c|c|c|c|c|}
\hline Effect & $\begin{array}{c}\text { Sum of } \\
\text { squares }\end{array}$ & $\begin{array}{c}\text { Degrees of } \\
\text { freedom }\end{array}$ & Mean square & F-value & P-value \\
\hline \multicolumn{6}{|l|}{ Male } \\
\hline Individuals & 0.0652 & 870 & 0.0001 & 3.7276 & $0^{*}$ \\
\hline Sides & 0.0075 & 30 & 0.0002 & 12.418 & $0^{*}$ \\
\hline Individual $\times$ Sides & 0.0175 & 870 & 0 & 0.6188 & $1^{\mathrm{ns}}$ \\
\hline Measurement Error & 0.0585 & 1800 & 3.2497 & --- & --- \\
\hline \multicolumn{6}{|l|}{ Female } \\
\hline Individuals & 0.0524 & 870 & 0.0001 & 2.69 & $0^{*}$ \\
\hline Sides & 0.0064 & 30 & 0.0002 & 9.8481 & $0^{*}$ \\
\hline Individual $\times$ Sides & 0.0195 & 870 & 0 & 0.7712 & $1^{\mathrm{ns}}$ \\
\hline Measurement Error & 0.0523 & 1800 & 2.9031 & --- & --- \\
\hline
\end{tabular}

Note: *highly significant $(\mathrm{p}<0.0001)$, ns not significant

Table 7. Procrustes ANOVA results of Channa striata from Lake Mainit in terms of sexes

\begin{tabular}{|c|c|c|c|c|c|}
\hline Effect & $\begin{array}{c}\text { Sum of } \\
\text { Squares }\end{array}$ & $\begin{array}{c}\text { Degrees of } \\
\text { Freedom }\end{array}$ & $\begin{array}{c}\text { Mean } \\
\text { Square }\end{array}$ & F-value & p-value \\
\hline \multicolumn{6}{|l|}{ Male } \\
\hline Individuals & 0.0761 & 870 & 0.0001 & 4.6312 & $0^{*}$ \\
\hline Sides & 0.0036 & 30 & 0.0001 & 6.2693 & $0^{*}$ \\
\hline Individual $\times$ Sides & 0.0164 & 870 & 0 & 0.388 & $1^{\text {ns }}$ \\
\hline Measurement Error & 0.0876 & 1800 & 4.8652 & --- & --- \\
\hline \multicolumn{6}{|l|}{ Female } \\
\hline Individuals & 0.1071 & 870 & 0.0001 & 7.4611 & $0^{*}$ \\
\hline Sides & 0.0032 & 30 & 0.0001 & 6.3652 & $0^{*}$ \\
\hline Individual $\times$ Sides & 0.0144 & 870 & 0 & 0.3905 & $1^{\mathrm{ns}}$ \\
\hline Measurement Error & 0.0761 & 1800 & 4.227 & --- & --- \\
\hline
\end{tabular}

Note: *highly significant $(\mathrm{p}<0.0001)$, ns not significant 
Furthermore, Table 8 and 9 show the results of Principal Component Analysis of $C$. striata samples in terms of sexes from Agusan Marsh and Lake Mainit respectively. Both sexes of $C$. striata sample from Agusan Marsh showed close percentage of FA (Male, PC1, $84.41 \%$ ) and (Female, PC4,85.41\%). PC1 showed that all areas covered by these landmarks were found to have greater asymmetry in males and PC3 in females. On the other hand, Lake Mainit $C$. striata male showed a total FA of $85.12 \%$ from PC1 to PC4 and its affected landmarks were greater in PCA 1 . While in female $C$. striata had a total FA of $80.89 \%$ from PC1 to PC4 in which PC3 had greater affected landmarks. The asymmetrical shape of $C$. striata from Agusan Marsh and Lake Mainit were compared and depicted in Figures 4 and 5.

The degree of closeness of FA is merely on behavior and characteristics and their preferred habitat. As observed in the deformation grid and PCA most of the affected portion of the body with many and variation was the anterior part of the body extended up to the middle areas which may be due to burrowing behavior and association of the anterior part with the lateral line system of the fish which enable them with their predatory skills and ability to live in stressed swampy and muddy habitat. The increase of Fluctuating Asymmetry variation of $C$. striata populations from two sites was followed by influence of their habitat quality. Noteworthy, that the samples from Agusan Marsh had higher $(7 \%)$ difference from Lake Mainit due to the fact that observed habitat had high turbidity, and local residence also attested that selected sampling rivers and creeks within the Agusan Marsh remained turbid throughout the year (Primavera and Tumanda Jr. 2008), unlike Lake Mainit that had clear waters (LMDA 2018).

\section{Sexual dimorphism}

Based on the cumulative report retrieved from relative warp analysis and discriminant analysis using PAST software, the resultant graphs showed overlap in the discriminant plot (Fig. 6) meaning shape differences between two sexes of $C$. striata specimens from Agusan Marsh and Lake Mainit are minimal. Hotellings $\mathrm{T}^{2}$ test results also revealed no significant sexual dimorphism for the body shape of the $C$. striata in all specimens from Agusan Marsh and Lake Mainit (Table 10). This is in line with the study of Saura and Andante (2018) who showed similar less significant sexual dimorphism in C. striata in Bunawan, Agusan River. Parker (1992) has pointed towards sperm competition, size buffering among other features in answer to the sexes being often so alike in size. However, some studies reported $C$. striata females are larger than males (Chaudhry 2010; Dumalagan 2017).

Table 8. The results of Principal Components of Channa striata from Agusan Marsh in terms of sexes

\begin{tabular}{|c|c|c|c|c|}
\hline PCA & $\begin{array}{c}\text { Individual } \\
\text { (symmetry) }\end{array}$ & $\begin{array}{c}\text { Sides } \\
\text { (Directional } \\
\text { Asymmetry) }\end{array}$ & $\begin{array}{l}\text { Interaction } \\
\text { (Fluctuating } \\
\text { Asymmetry) }\end{array}$ & Landmarks affected \\
\hline \multicolumn{5}{|l|}{ Male } \\
\hline $\mathrm{PC} 1(\%)$ & 44.68 & $100 \%$ & 43.81 & $1,2,5,6,7,9,11,12,13,14,15,16,17$ \\
\hline $\mathrm{PC} 2(\%)$ & 21.90 & & 20.45 & $1,2,3,5,7,9,10,11,12,14,15,16$ \\
\hline PC3 $(\%)$ & 14.62 & & 12.94 & $1,6,7,10,11,14,15,16,17$ \\
\hline PC4 (\%) & 5.31 & & 7.07 & $2,5,7,8,9$ \\
\hline Overall\% & 86.51 & & 84.27 & \\
\hline \multicolumn{5}{|l|}{ Female } \\
\hline $\mathrm{PC} 1(\%)$ & 52.62 & $100 \%$ & 47.80 & $1,2,3,6,10,13,14,15,16,17$ \\
\hline PC2 $(\%)$ & 16.57 & & 20.31 & $1,2,7,9,10,11,12,14,16,17$ \\
\hline PC3 (\%) & 10.09 & & 9.07 & $1,2,3,5,6,8,9,10,11,12,13,14,15,17$ \\
\hline PC4 $(\%)$ & 5.31 & & 8.23 & $1,2,3,5,9,11,12,16,17$ \\
\hline Overall\% & 84.59 & & 85.41 & \\
\hline
\end{tabular}

Table 9. The results of Principal Components of Channa striata from Lake Mainit in terms of sexes.

\begin{tabular}{ccccc}
\hline PCA & $\begin{array}{c}\text { Individual } \\
\text { (symmetry) }\end{array}$ & $\begin{array}{c}\text { Sides } \\
\text { (Directional } \\
\text { Asymmetry) }\end{array}$ & $\begin{array}{c}\text { Interaction } \\
\text { (Fluctuating } \\
\text { Asymmetry) }\end{array}$ & Landmarks affected \\
\hline Male & & & & \\
PC1 (\%) & 54.20 & $100 \%$ & 32.81 & $1,2,5,6,7,9,11,12,13,14,15,16,17$ \\
PC2 (\%) & 19.25 & & 26.02 & $1,2,3,5,7,9,10,11,12,14,15,16$ \\
PC3 (\%) & 8.05 & & 13.09 & $1,6,7,10,11,14,15,16,17$ \\
PC4 (\%) & 5.62 & & 7.43 & $2,5,7,8,9$ \\
PC5 (\%) & --- & 5.77 & \\
Overall\% & 87.12 & & 85.12 & \\
Female & & & & \\
PC1 (\%) & 67.25 & $100 \%$ & 30.39 & $1,2,3,6,10,13,14,15,16,17$ \\
PC2 (\%) & 14.68 & & 22.07 & $1,2,7,9,10,11,12,14,16,17$ \\
PC3 (\%) & 6.59 & & 11.82 & $1,2,3,5,6,8,9,10,11,12,13,14,15,17$ \\
PC4 (\%) & --- & 10.12 & $1,2,3,5,9,11,12,16,17$ \\
PC5 (\%) & --- & & 6.49 & \\
Overall\% & 88.52 & & 80.89 & \\
\hline
\end{tabular}



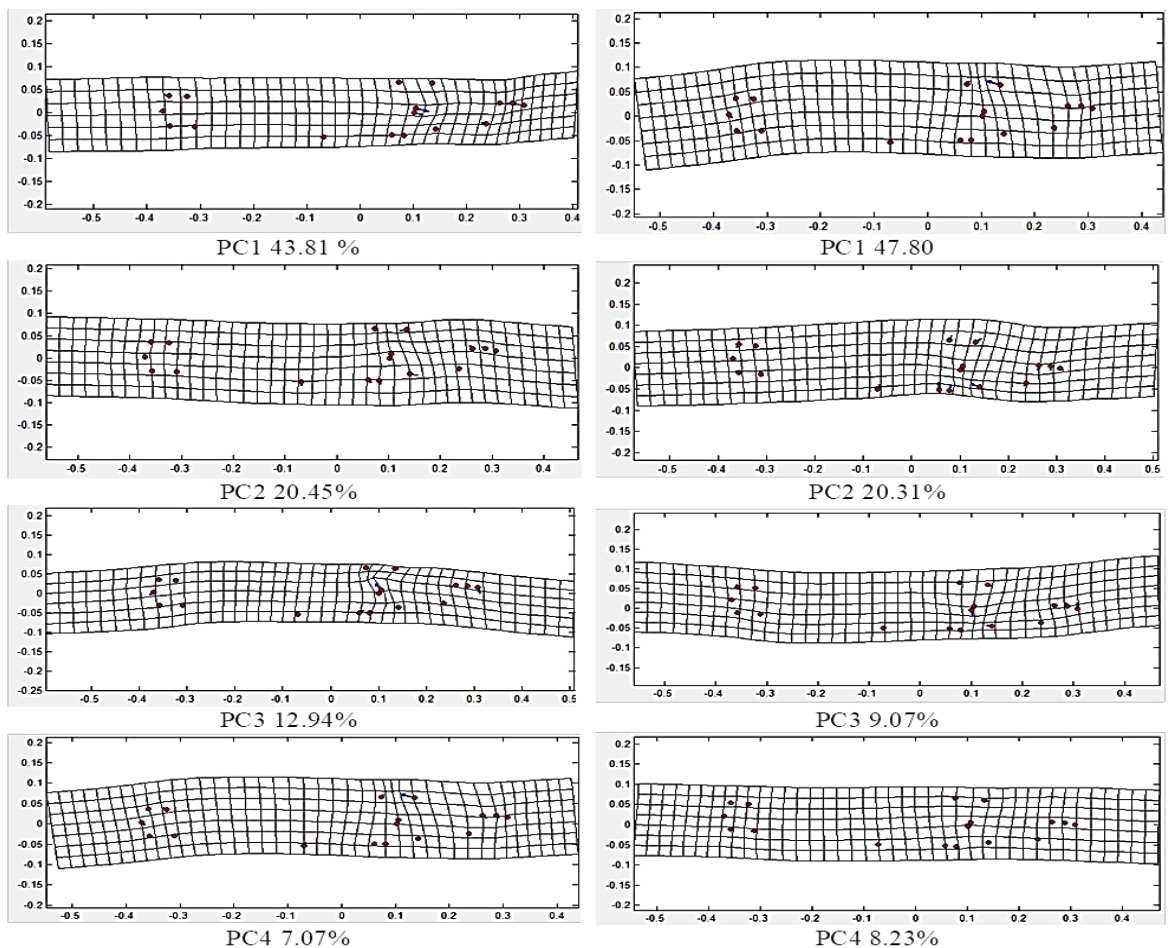

Figure 4. The male (first column) and female (second column) fishes from Agusan Marsh with the affected landmarks shown in PCAdeformation grid.
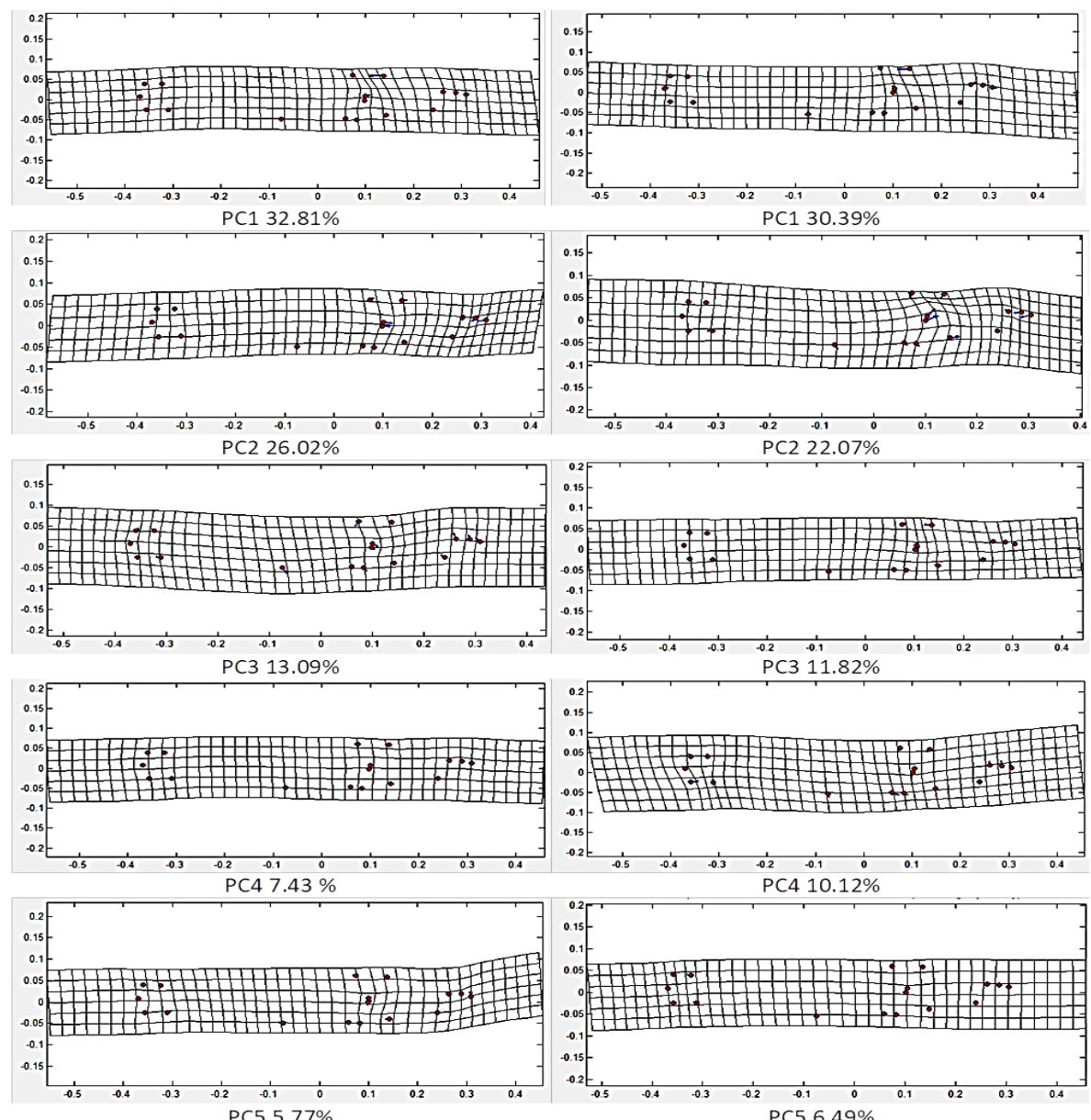

Figure 5. The male (first column) and female (second column) fishes from Lake Mainit with the affected landmarks shown in PCAdeformation grid. 

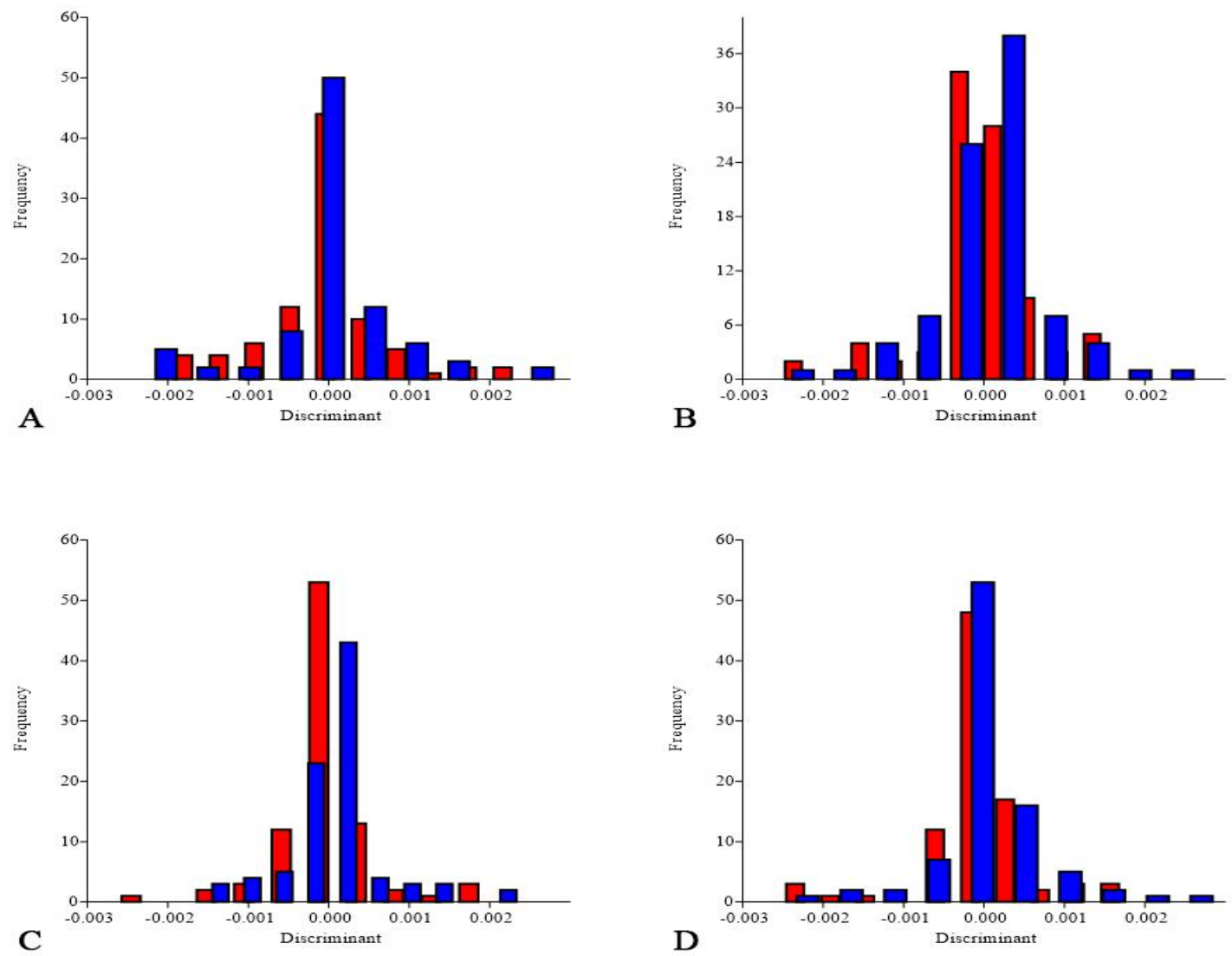

Figure 6. Discriminant plot of sexual dimorphism: A (left flank) and B (right flank) from Agusan Marsh; C (left flank) and D (right flank) from Lake Mainit.

Table 10. Result of Discriminant analysis of Sexual Dimorphism of Channa striata.

\begin{tabular}{lcccc}
\hline $\begin{array}{l}\text { Discriminant } \\
\text { analysis }\end{array}$ & \multicolumn{2}{c}{ Agusan Marsh } & \multicolumn{2}{c}{ Lake Mainit } \\
& Left flank & Right flank & Left flank & Right flank \\
\hline Hotelling's $T^{2}$ & 2.9337 & 2.1325 & 1.7599 & 2.1011 \\
F-value & 3.1131 & 2.263 & 1.8676 & 2.2296 \\
p-value & 1 & 1 & 1 & 1 \\
\hline
\end{tabular}

Table 11. Physico-Chemical Parameters of both sampling areas gathered in the month of December 2018.

\begin{tabular}{|c|c|c|c|c|c|c|}
\hline \multirow[b]{2}{*}{ Sampling area } & \multicolumn{6}{|c|}{ Parameters } \\
\hline & $\begin{array}{c}\text { TSS } \\
\text { (ppm) }\end{array}$ & $\begin{array}{c}\text { TDS } \\
(\mathbf{p p m})\end{array}$ & $\begin{array}{c}\text { DO } \\
\text { (ppm) }\end{array}$ & pH & $\begin{array}{c}\text { Salinity } \\
\text { (ppm) }\end{array}$ & $\begin{array}{c}\text { Temperature } \\
\left({ }^{\circ} \mathrm{C}\right)\end{array}$ \\
\hline *Tagbuyawan & 10.5 . & 101 & 7.86 & 7.73 & 0.03 & 29.35 \\
\hline *Mayag & 3.4 & 100 & 7.52 & 8.07 & 0.03 & 29.50 \\
\hline *Magpayang & 11.8 & 113 & 8.93 & 7.07 & 0.03 & 29.30 \\
\hline *Magtiaco & 72.4 & 125 & 12.1 & 7.35 & 0.01 & 28.95 \\
\hline *Jaliobong & 15.0 & 101 & 7.73 & 7.67 & 0.01 & 29.66 \\
\hline *Kalinawan & 31.0 & 105 & 7.97 & 7.48 & 0.01 & 29.16 \\
\hline **Lake Mihaba & 47.8 & 92 & 3.37 & 6.9 & 0.05 & 28.52 \\
\hline **Lake Mihaba Creek (outlet) & 37.4 & 73 & 3.42 & 6.93 & 0.04 & 28.81 \\
\hline **Agusan river (downstream) & 61.0 & 153 & 3.44 & 8.14 & 0.11 & 28.94 \\
\hline **Loreto river (downstream) & 30.0 & 145 & 3.46 & 7.87 & 0.11 & 28.65 \\
\hline **Agusan river (upstream) & 63.2 & 226 & 3.42 & 8.02 & 0.17 & 29.06 \\
\hline ** Sumilao (downstream) & 57.60 & 104 & 4.55 & 7.8 & 0.07 & 28.72 \\
\hline
\end{tabular}

Note: Legend: *Lake Mainit sampling stations, ** Agusan Marsh sampling stations 
Table 12. Comparisons of Physico-chemical parameters and concentrations of $\mathrm{CN}, \mathrm{Fe}, \mathrm{Zn}, \mathrm{Cu}, \mathrm{Pb}$ to DENR standards (as sampled in Lake Mainit sampling stations on November 11, 2018, and Agusan Marsh sampling stations on December 05, 2018.

\begin{tabular}{llll}
\hline \multirow{2}{*}{ Parameters } & \multicolumn{1}{c}{ Available range } & DENR \\
\cline { 2 - 4 } & Lake Mainit & Agusan Marsh & 80 \\
TSS (ppm) & $3.4-10.5$ & $30-63.2$ & $96-100$ \\
TDS (ppm) & $100-125$ & $73-226$ & 5 \\
DO (ppm) & $7.52-12.1$ & $3.37-4.55$ & $6.5-9.0$ \\
pH & $7.07-8.07$ & $6.9-8.14$ & Nd \\
Salinity (ppm) & $0.01-0.03$ & $0.04-0.17$ & 2 \\
Fe (ppm) & $<0.01-0.09$ & $0.46-3.39$ & 1.5 \\
Zn $(\mathrm{ppm})$ & $<0.01$ & $<0.01$ & 0.02 \\
$\mathrm{Cu}(\mathrm{ppm})$ & $<0.01$ & $<0.01$ & 0.02 \\
$\mathrm{~Pb}(\mathrm{ppm})$ & $<0.01$ & $<0.01-0.01$ & 0.1 \\
$\mathrm{CN}-(\mathrm{ppm})$ & $<0.01$ & $<0.01$ & \\
\hline
\end{tabular}

Note: nd: no data

\section{Physico-chemical, cyanide and four base metals}

Table 11 shows the result of the physicochemical parameter in the sampling area of Lake Mainit and Agusan Marsh using multiparameter test. In Lake Mainit sampling stations, Magtiaco river mouth recorded the highest total suspended solids, total dissolved solids and dissolved oxygen level. It may be due to the heavy coarse load and runoff from the landslide in small-scale mining areas of upstream mountainous areas. during Typhoon (Sanba) Basyang of February 2018. Salinity, pH and temperature were mostly the same among other sampling sites. In Agusan Marsh sampling area, upstream and downstream of Agusan river were observed with high total suspended solids, total dissolved solids, $\mathrm{pH}$ and temperature due to the fact that Agusan River is the receiver of almost eleven tributaries including the other sampling sites. The dissolved oxygen and salinity were mostly the same among other sampling sites in Agusan Marsh sampling area.

Furthermore, the analysis of four base metals and Cyanide indicated that Zinc, Copper, Lead, and Cyanide levels were in less than detection limit of $0.01 \mathrm{ppm}$ in Lake Mainit and Agusan Marsh sampling stations, except the value of Lead was 0.01 in Lake Mihaba Creek (outlet) of Agusan Marsh. In terms of Iron content, Magtiaco (0.09 ppm) in Lake Mainit had the highest value while other locations of the said sampling site had values ranging from $<0.01-0.01 \mathrm{ppm}$. Agusan Marsh sampling stations had varied Iron content all above the detectable limit of 0.01 ppm ranging from 0.46 in Agusan river (upstream) to 3.39 in Lake Mihaba.

Table 12, shows the range and comparison of the water parameters that were tested in the selected sampling sites to the DENR recommended water quality standards and contamination limit on toxic and deleterious substances. The range of the parameter values was observed high mostly in Agusan Marsh TSS, TDS, Salinity and Iron (Fe) while Dissolve oxygen had low values compared to Lake Mainit. Out of the four base metals, only Iron (Fe) was recorded above detectable limit and observed high in Agusan Marsh. Cyanide was below detectable limit and acceptable to the DENR standards. Total dissolved solids in both Lake Mainit and Agusan Marsh were not acceptable to the standard set by DENR that should not surpass 96-100 ppm except in Lake Mihaba and its outlet creek that was in the acceptable limit (see table 3). Total suspended solids, TSS, $\mathrm{pH}, \mathrm{Zn}, \mathrm{Cu}, \mathrm{Pb}, \mathrm{CN}^{-}$values of Lake Mainit and Agusan Marsh were acceptable to the recommended standards. On the other hand, in terms of Dissolved Oxygen level, Agusan Marsh is not acceptable to the recommended standards. At the same time, Iron $(\mathrm{Fe})$ level specifically in Lake Mihaba and its outlet in Agusan Marsh were not acceptable to the DENR standards. Salinity however owns at the level characterized by freshwater.

The values of selected physicochemical parameters differed from each habitat such as dissolved oxygen level and Iron which recorded higher in Agusan Marsh compared to Lake Mainit. These differences due to the surroundings and the ecosystem type of each habitat. The Agusan Marsh is an extensive floodplain in the middle of the Agusan River Basin in eastern Mindanao which served as stopped drainage of waters from rivers, creeks and tributaries mainly in the provinces of Agusan del Norte, Agusan del Sur and Compostela Valley and development for agriculture, construction of dams and reservoirs for irrigation, deliberate or accidental introductions of exotic species, e.g., tilapia, carps, janitor fish, and golden apple snail, and logging in the watershed areas. (Primavera and Tumanda Jr. 2008). While Lake Mainit is an oligotrophic lake based on its physicochemical, natural productivity and optical properties and morphometric characteristics (Tumanda Jr. et al. 2003). The study provided that $C$. striata which is a food source and bioresources for livelihood generation can be propagated in freshwater aquaculture even in a stressful environment.

In conclusion, the landmark-based geometric morphometric was a useful tool in describing the fluctuating asymmetry and sexual dimorphism of Channa striata. The statistical results showed high variations $(\mathrm{p}<$ 0.0001 ) on the left and right side of the bilateral represented by $79.22 \%$ in Agusan Marsh specimens and $72.35 \%$ in Lake Mainit specimens which may be considered as relatively high Fluctuating Asymmetry. The affected landmark points and variation are observed in the cephalic, pectoral, and caudal regions which may be due to burrowing behavior and association of the lateral line system among fishes that thrive in high turbid waters and 
low oxygen. Further, the physicochemical analysis reveals that Agusan Marsh had low dissolved oxygen, TDS, and Iron deviates to the national water quality standards while Lake Mainit is within permissible limits. On the other hand, the total FA in terms of sexes, Agusan marsh had $84.27 \%$ and $85.41 \%$, while Lake Mainit had $85.12 \%$ and $80.89 \%$ respectively in males and females. The fairly similar FA\% based on the 17 landmark points of all $C$. striata population confirms to less or no sexual dimorphism of fish in the study area. The present study contributes essential information about the body variations of $C$. striata and the condition of Agusan marsh basin and Lake Mainit and importance of FA in determining the habitat condition the fact that organisms, $C$. striata preferred high turbidity and thrived in stress condition. Further study is needed regarding Fluctuating Asymmetry of $C$. striata in relation to seasonal variations.

\section{REFERENCES}

Adams DC, Rohlf FJ, Slice DE. 2009. Geometric Morphometrics: Ten Years of Progress Following the 'Revolution'. Ital J Zool 71: 5-16. DOI: 10.1080/11250000409356545.

Beasley DAE, Bonisoli-Alquati A, Mousseau TA. 2013. The use of fluctuating asymmetry as a measure of environmentally induced developmental instability: A meta-analysis. Ecol Indic 30: 218-226. DOI: 10.1016/j.ecolind.2013.02.024.

Broadley DG. 1965 Serpentine Systematics-A Review of Taxonomic Characters. J Herpetol Assoc Afr 1: 7-10. DOI: 10.1080/04416651.1965.9650678.

Cagauan AG. 2007. Exotic aquatic species introduction in the Philippines for aquaculture-A threat to biodiversity or a boon to the economy?. J Environ Sci Manag 101: 48-62.

Chaudhry S. 2010. Channa striata. The IUCN Red List of Threatened Species 2010: e.T166563A6237224. https://www.iucnredlist.org/species/166563/6237224

Coda JA, Martínez JJ, Steinmann AR, Priotto J, Gomez MD. 2017. Fluctuating Asymmetry as an Indicator of Environmental Stress in Small Mammals. Mastozool Neotrop 24: 313-321. DOI: 10.1016/B978-0-08-045337-8.00117-0.

Dumalagan FA, Garcines JV, Boyles LZ. 2017. Reproductive Biology, Length-Weight Relationship and Condition Factor of Channa striata (Bloch, 1793) from tributaries of Lake Kilobidan, Agusan Marsh, Philippines. Intl J Comput Commun Instrum Eng 4: 78-81. DOI: 10.15242/ijccie.ae0117114

Guerrero III RD. 2014. Impacts of Introduced Freshwater Fishes in the Philippines (1905-2013): A Review and Recommendations Philipp J Sci 143: 49-59.

Jumawan JH, Abastillas SOMAL, Dicdican MJA, Cabag MB, Gamolo EM, Velasco JPB, et al. 2016. Fluctuating asymmetry in the body shapes of goby fish Glossogobius giuris from Agusan River, Butuan City, Agusan del Norte, Philippines. AACL Bioflux 9: 133-142.

Kasumyan AO. 2003. The Lateral Line in Fish: Structure, Function, and Role in Behavior. J Ichthyol 43: S175-S213.

Leary RF, Allendorf FW. 1989. Fluctuating asymmetry as an indicator of stress: Implications for conservation biology. Trends Ecol Evol 4: 214-217. DOI: 10.1016/0169-5347(89)90077-3

Lymbery AJ. 1992. The environmental control of colouration in a bushcricket, Mygalopsis marki Bailey (Orthoptera: Tettigoniidae).
Biol J Linn Soc 45: 71-89. DOI: 10.1111/j.10958312.1992.tb00632.x.

McCombe PA, Greer JM. 2014. Sexual dimorphism in the Immune System. In: Mackay IR, Rose NR (eds.). The Autoimmune Diseases 5th. Academic Press, Elsevier, Amsterdam. DOI: 10.1016/B978-0-12384929-8.00024-1

Mittal AK, Agrawal N. 1994. Modifications in the epithelia of lips and associated structures of the predatory murrel (Channa striata). J Appl Ichthyol 10: 114-122. DOI: 10.1111/j.1439-0426.1994.tb00150.x.

Mitteroecker P, Gunz P. 2009. Advances in Geometric Morphometrics. Evol Biol 36: 235-247. DOI: 10.1007/s11692-009-9055-x.

Musikasinthorn P. 2004. Channoidei (snakeheads). In: Hutchins M et al. (eds). Grizmek's Animal Life Encyclopedia Vol. 5, 2 ${ }^{\text {nd }}$ ed. Gale Virtual Reference Library, Detroit, USA.

Niskanen M, Ruff CB, Holt B, Sládek V, Berner M. 2017. Temporal and Geographic Variation in Body Size and Shape of Europeans from the Late Pleistocene to Recent Times. In: Ruff CB (eds). Skeletal Variation and Adaptation in Europeans: Upper Paleolithic to the Twentieth Century. John Wiley \& Sons, Inc., New York DOI: 10.1002/9781118628430.ch4

Olvido AE, Mousseau TA. 2012. Geographical Variation. In: Encyclopedia of Life Sciences. John Wiley \& Sons Ltd, Chichester. DOI: 10.1002/9780470015902.a0001736.pub3.

Parker G. 1992. The Evolution of Sexual Size Dimorphism In Fish. J Fish Biol 41: 1-20. DOI: 10.1111/j.1095-8649.1992.tb03864.x.

Parsons PA. 1992. Fluctuating Asymmetry: A Biological Monitor of Environmental And Genomic Stress. Heredity 68: 361-364. DOI: 10.1038/hdy.1992.51.

Phen C, Thang TB, Baran E, Vann LS. 2005. Biological Reviews of Important Cambodian Fish Species, Based on Fishbase 2004. WorldFish Center and Inland Fisheries Research and Development Institute, Phnom Penh, Cambodia.

Ralls K, Mesnick S. 2009. Sexual Dimorphism. In: Perrin WF, Würsig B, Thewissen JGM (eds). Encyclopedia of Marine Mammals $\left(2^{\text {nd }}\right.$ ed). Academic Press, Elsevier, Amsterdam. DOI: 10.1016/B978-0-12373553-9.00233-9.

Quirog DG, Tabugo SR. 2015. Population Analysis Via Fluctuating Asymmetry in The Wings of Aedes albopictus from selected barangays in Iligan City, Philippines. J Entomol Zool Stud 3: 34-39.

Santos JC, Alves-Silva E, Cornelissen TG, Fernandez GW. 2013. The Effect of Fluctuating Asymmetry and Leaf Nutrients On Gall Abundance and Survivorship. Basic Appl Ecol 14: 489-495. DOI: 10.1016/j.baae.2013.06.005.

Sayer MDJ. Adaptations of Amphibious Fish for Surviving Out of Water. Fish Fish 6: 186-211.

Seigel RA, Ford NB. 2001. Phenotypic plasticity in reproductive traits: geographical variation in plasticity in a viviparous snake. Funct Ecol 15: 36-42. DOI: 10.1046/j.1365-2435.2001.00492.x.

Sullivan RM, Best TL. 1997. Effects of environment on phenotypic variation and sexual dimorphism in Dipodomys simulans (Rodentia: Heteromyidae). J Mammal 78: 798-810. DOI: 10.2307/1382937.

Tomkins JL, Kotiaho JS. 2001. Fluctuating Asymmetry. In: Encyclopedia of Life Sciences. DOI: 10.1038/npg.els.0003741.

Vitt LJ, Caldwell JP. 2014. Communication and Social Behavior. In: Vitt LJ, Caldwell JP (eds). Herpetology an Introductory Biology of Amphibians and Reptiles ( $4^{\text {th }}$ ed). Academic Press-Elsevier, Amsterdam. DOI: 10.1016/B978-0-12-386919-7.00009-5.

Webster M, Sheets DH. 2010. A Practical Introduction to LandmarkBased Geometric Morphometrics. In: Alroy J, Hunt G (eds). Quantitative Methods in Paleobotany. The Paleontological Society Papers. Cambridge University Press, UK.

Wu Z, Yu D, Wang Z, Li X, Xu X. 2015. Great influence of geographic isolation on the genetic differentiation of Myriophyllum spicatum under a steep environmental gradient. Sci Rep 5: 15618. DOI: $10.1038 /$ srep 15618 . 